\title{
CORRIGENDUM
}

\section{Effects of divorce on Dutch boys' and girls' externalizing behavior in Gene $\times$ Environment perspective: Diathesis stress or differential susceptibility in the Tracking Adolescents' Individual Lives Survey study?-CORRIGENDUM}

\section{ESTHER NEDERHOF, ${ }^{a}$ JAY BELSKY, ${ }^{b-d}$ JOHAN ORMEL, $^{a}$ AND ALBERTINE J. OLDEHINKEL ${ }^{a}$ \\ ${ }^{a}$ University Medical Center Groningen; ${ }^{b}$ University of California, Davis; ${ }^{c}$ King Abdulaziz University; and ${ }^{d}$ Birkbeck University of London}

doi:10.1017/S0954579412000454, published by Cambridge University Press, 6 July 2012

Table 1 in our original article contained an error in the gene labels, in which DRD2 and DRD4 were switched. The table is reprinted herein with them corrected. The authors sincerely apologize for the error and any problems this may have caused.

Table 1. Partial and bivariate correlations between dependent and all independent variables for boys (above diagonal) and girls (below diagonal)

\begin{tabular}{|c|c|c|c|c|c|}
\hline & External. & Divorce & $\begin{array}{c}\text { DRD4 (Short/ } \\
\text { Short; } 7^{+} \text {Carrier) }\end{array}$ & $\begin{array}{c}\text { DRD2 (G/G; } \\
\text { A-Carrier) }\end{array}$ & $\begin{array}{c}C O M T \\
\text { (A-Carrier; G/G) }\end{array}$ \\
\hline External. & & $.144 *$ & $-.103 *$ & -.043 & .005 \\
\hline Divorce & $.096 *$ & & $.094 *$ & .028 & .019 \\
\hline DRD4 (short/short; $7^{+}$carrier) & .054 & -.015 & & .071 & -.024 \\
\hline DRD2 (G/G; A-carrier) & .016 & .010 & .068 & & .053 \\
\hline COMT (A-carrier; G/G) & -.006 & .061 & .051 & -.037 & \\
\hline
\end{tabular}

Note: DRD4, Dopamine receptor D4; DRD2, dopamine receptor D2; COMT, catechol-O-methyltransferase.

$* p<.05$.

\section{Reference}

Nederhof, E., Belsky, J., Ormel, J., \& Oldehinkel, A. J. (2012). Effects of divorce on Dutch boys' and girls' externalizing behavior in Gene $\times$ Environment perspective: Diathesis stress or differential susceptibility in the
Tracking Adolescents' Individual Lives Survey study? Development and Psychopathology, 24, 929-939. 